\title{
The foreign exchange market in Barcelona at the beginning of the fifteenth century
}

\author{
ANGELA ORLANDI and GIACOMO TOSCANO \\ University of Florence
}

\begin{abstract}
Based on the reconstruction of the monetary flows of a merchant-banking company operating in Barcelona at the beginning of the fifteenth century, this study aims to understand the reasons behind exchange-rate variations in the local currency with respect to the principal European markets, as well as the modalities and predictability of such oscillations. By using real rather than 'hearsay' rates, we present new assessments of the seasonal character of exchange rates and their sensitivity to conditions of currency abundance or shortage. In addition, econometric analysis shows that exchange-rate volatility was quite modest and dependent on geographic and macroeconomic factors, such as the system of commercial flows.
\end{abstract}

Keywords: exchange-rate market, exchange-rate volatility, bill of exchange, Barcelona fifteenth century

JEL classification: $\mathrm{C}_{5} 8, \mathrm{~F}_{3} \mathrm{I}_{1} \mathrm{~N}_{13}, \mathrm{~N}_{23}$

\section{I}

The bill of exchange and the currency market (today's foreign exchange market) are among the most interesting and at the same time complex themes of economic historical research. We are indebted to Raymond De Roover (1953) and Federigo Melis (I972) for their studies of the workings of bills of exchange and for their understanding of the mechanisms of speculation that these made possible. ${ }^{1}$ Their research cleared the way for the reconstruction of the financial market of preindustrial Europe.

Angela Orlandi, Department of Economics and Management, University of Florence, Via delle Pandette, 32, 50127, Florence, Italy, email: angela.orlandi@unifi.it; Giacomo Toscano, Scuola Normale Superiore, Piazza dei Cavalieri, 7, 56126, Pisa, Italy; Department of Economics and Management, University of Florence, Via delle Pandette, 32, 50 127, Florence, Italy, email: giacomo. toscano@sns.it. Angela Orlandi authored the first four sections of this article and the sixth section. The fifth section is the work of both authors, based on the econometric analysis by Giacomo Toscano. The authors are grateful to the editor, Rui Esteves, and two anonymous referees for their helpful suggestions and insightful comments, which undoubtedly improved the quality of the manuscript.

${ }^{1}$ See also Sapori (1970) and Sayous (1975), who are among the first scholars to have studied these themes. 
Indeed, from the late I960s many scholars began to devote their attention to the circulation of currencies by means of bills of exchange. A number of studies have examined the fairs of Champagne, where by the thirteenth century bills were bought and sold together with goods; others, meanwhile, have analyzed those of Geneva, Lyon, Medina del Campo, Besançon and Piacenza, which saw a gradual increase in this business, culminating in the rise of Novi Ligure, which in the seventeenth century attracted the elite of international finance - a true City avant la lettre. ${ }^{2}$

Still today, the circulation of capital through the networks of fairs represents a topic of considerable interest among economic historians. Recently, however, other related themes have also gained ground: many scholars have moved their focus to the broad subject of the price of money, using the 'hearsay' ${ }^{3}$ exchange rates indicated in commercial correspondence to study and recreate historical series, which they in turn analyze to understand rate fluctuations and variations over different times of the year; in addition, they have investigated the possibility of using foreign exchange transactions to dodge the prohibition of applying interest (Koyama 20I0). Other scholars, meanwhile, have compared exchange rates in bills with those of public debt and consumer credit (Rubin 20I0; Bell, Brooks and Moore 20I3, 20I7a; Orlandi 20I6). ${ }^{4}$ Finally, some researchers have aimed to clarify the reasons behind the issuing of bills of exchange and the ways these were employed: in some cases, unusual appropriations have come to light, such as the use of bills as simple instruments of money transfers (Nigro 20I6).

This variegated historiographical framework provides the context for our attempt to answer several questions. Above all this work aims to follow the monetary flows set in motion by a late medieval company which was consistently involved in exchange operations. Analysis of monetary flows makes possible a sort of internal study of a company, in particular to comprehend the specific weight of a firm on the market on the basis of the bills of exchange which it issued and received. Such a line of inquiry inevitably leads to the attempt to understand the reasons behind exchange-rate oscillations, the ways in which these occurred and their level of predictability. To this end, we identified a source which seems able to shed light on both of these topics, namely the book of

2 Numerous studies treat the questions of monetary circulation by means of bills of exchange, such that it is practically impossible to present a historiographical outline of the theme. We refer here only to the most recent studies, especially those devoted to the various European fairs: Börner and Hatfield (2O I 7); Casado Alonso (20 I 5); Flandreau et al. (2009); Marsilio (20 I Oa, b, 20 I I a, b, c, 20 I 2a, b, c, 20 I 4, 20 I 5 a, b, 2016); Martínez Ruiz (2004); Neal (2000); Nogues-Marco (20I7); Pezzolo and Tattara (2008); Quinn and Roberds (2006); Rubin (2010); Sánchez del Barrio (2015). For a complete picture of studies of exchange fairs and the European money market, see Marsilio (2018).

3 'Hearsay' rates were those which prevailed in a given moment on a given market. These were the rates that commercial agents assumed would be applied to exchange contracts.

4 Bell, Brooks and Moore (20I $7 \mathrm{~b}$ ) have also examined questions relating to variations in the purchasing power of money in medieval Europe. 
exchange bills from the Datini company of Barcelona, which contains details of the exchange contracts it made in $\mathrm{I}_{4} \mathrm{O} 3 .^{5}$

This account book constitutes a reliable primary source for this type of analysis, as it has allowed us to work with the rates which were effectively applied - the actual prices involved - rather than the 'hearsay' rates mentioned above. We opted not to use 'hearsay' rates because the data at our disposal show a systematic difference with respect to the real rates. This discrepancy is by no means a minor one. Analysis of the data at our disposal relative to all the markets with which Barcelona had exchange transactions that year reveals that in 57.56 per cent ${ }^{6}$ of cases the real exchange rate was higher than the 'hearsay' one, while in 23.84 per cent it was lower; in only I8.60 per cent of transactions did the two values coincide. Observation of the individual exchange markets confirms that correspondence of the real and 'hearsay' rates was quite rare. For example, this was the case in only 6.67 per cent of transactions in Avignon and 9.09 per cent in Bruges. The highest percentages of matching rates, which are still on the whole low, are found in Florence and Genoa (26.92 per cent and 30.00 per cent, respectively). All other markets show values of between I6.67 per cent and I2.50 per cent.

Our findings also enable us to highlight that the percentages in which real exchange rates were higher than 'hearsay' ones ranged from a maximum of 86.67 per cent in Avignon to a minimum of 23.08 per cent for Florence; with regard to the opposite case, the lowest percentage (6.67 per cent) was recorded once again in Avignon and the highest in Pisa (57.I4 per cent). It is further of interest to note that the real exchange rate tended to be higher than the 'hearsay' one above all in the winter months (December-March), while the contrary is evident during the rest of the year. The greatest difference between the two types of exchange rates was observed in the case of Genoa, where the difference between the real and 'hearsay' rate reached a maximum of 18.60 per cent during the month of February.

These data are quite useful for explaining the particular rate fluctuations of certain markets, which we will presently analyze in more detail. It is clear, then, that using 'hearsay' rates would have caused systematic error and produced distorted results in the analysis of exchange-rate volatility. ${ }^{7}$ From this documentation we created a database which collects financial operations concluded by the Datini company of Barcelona between 6 March I 403 and Io March I 404. Examination of these data was supplemented by an econometric study with both univariate and multivariate analyses.

We are well aware that this study considers only a single firm and treats a limited timeframe. We must bear in mind, though, that the Datini group was one of the most important companies operating in the regions of Catalonia and Aragon, controlling

5 This account book forms part of the important Fondo Datini, preserved at the State Archive of Prato. State Archive of Prato, Fondo Datini (ASPo, Datini), 842, Book of Exchange Bills labeled 'G'.

6 Percentages are calculated as the difference between the 'hearsay' and the real rate over the 'hearsay' rate.

7 Data cited here are taken from correspondence sent from Barcelona in 4403 to other branches of the Datini group. 
the trade in Maestrazgo wool, a crucial raw material in the economy of the era, in oligopsonistic fashion (Orlandi 20IOa, 20Iob). As we will see below, the Barcelonan firm played the leading role in the Catalan holding company, collaborating with and supporting its two sister branches of the company of Catalonia (Valencia and Mallorca) in a great variety of ways. On the one hand, the cooperation of the three branches enhanced the polycentric character of the Catalan-Aragonese economy, which was based on the three cities which interacted through a network of ports and large and small markets in the territories of the Aragonese crown. On the other hand, these Datini firms had a significant impact on the commodities trade with the major economic centers of the Mediterranean and northern Europe (Orlandi 20I9).

In this framework, much of the activity of the Barcelonan branch was financial, as it managed not only the cash flows within the Datini system but also the movement of money in the broadest sense of the term (Orlandi 20I9). Not by chance, then, do we find that of the 5,4I 7 bills of exchange that have come down to us (conserved today in their original form at the Datini Archive in Prato) 2,587 were issued in Barcelona, 378 in Valencia and I 6 in Palma. While these figures show the important financial role played by Barcelona, we must bear in mind that we do not know how many bills have been lost.

With regard to the brief period under consideration in our analysis, we will see that over I,ooo financial operations were transacted in those twelve months, for an average of over 80 per month.

As cities launched upon a period of continuous growth from the mid-fourteenth century, the monetary economy began to expand as a result of a reduction in forms of payment in kind. Yet while the trend toward monetization rose, thereby increasing the need for financial capital, the quantity of circulating money did not keep pace. The problem of scarce liquidity was therefore a basic reality of the most advanced cities of the late Middle Ages. The problem was faced in various ways: deferred payments, down payments in raw materials or money, loans to a business on the part of a partner through a sovraccorpo, ${ }^{8}$ but above all by means of diverse operations of usury and new forms of payment, including bills of exchange and written orders, which in Tuscany were transformed into veritable bank cheques (Melis I972, pp. 75-IO3).

These new forms derived from mechanisms of abstracting from the concept of money, operations which merchants engaged in from the middle of the fourteenth century. In part, such operations were successful thanks to the refinement of linguistic

8 Sovraccorpo indicates those sums of money which were not distributed as dividends and therefore remained in possession of the company. 
jargon, that is, to the invention and use of formalized techniques for describing economic phenomena (Puncuh 2002; Toccafondi 2004). The intrinsic value of metallic money was replaced by the value of a written document in the form of a bill of exchange, bank transfer or bank cheque, which allowed money to change hands more conveniently and safely.

With the bill of exchange, the operator needing to transfer funds to another market was the remitter (the purchaser of the foreign currency); he deposited a certain sum with the taker, receiving in return a payment order which he then sent to the payee. When the latter received the bill, he went to the taker's foreign representative (drawee), who upon accepting the payment order signed by the taker paid him the sum indicated in the document in the local currency.

The bill of exchange was used in a variety of ways. As we have just indicated, its typical function corresponded to today's money transfer, ${ }^{9}$ namely an international payment that took place without the physical circulation of money. The remitter transferred money in the local currency to a payee, who received the equivalent in the currency of his market. The intermediaries in the operation were the taker and the drawee, who had perforce to maintain close correspondence - and not only because of their geographical distance - so as to consolidate over time their respective functions of debtor and creditor in order to be able to execute the contracts of exchange.

Bills of exchange could also be used as tools for credit and speculation. Thanks to their thorough knowledge of foreign exchange markets and their wide-ranging network of relations, Florentine merchants made loans or speculated on the basis of the difference between exchange rates in two cities, by means of an exchange of bills (with the remitter of the first bill becoming the payee of the second, and the drawee now functioning as beneficiary). In the case that a bill of exchange was used as a loan, it was often guaranteed by means of a preliminary agreement in which the parties established the amount of the return exchange (a cambium siccum, or 'dry exchange'). ${ }^{10}$ This was understandably a practice that met with strong condemnation on the part of the Church, as the parties could conceal the interest rate in the exchange rate of the second bill.

9 For the definition of money transfer, see Bonis and Vangelisti (2019, pp. I45-6).

10 According to Richard Goldthwaite (2013, pp. 300-I), Florentine merchants used the mechanism of protest to turn their credit potential to their advantage: by this procedure, the drawee protested the validity of the bill, thus allowing the payee to draw a new one against the taker, to be paid to the original deliverer, that is, the remitter. The latter effectively received the money lent directly from the taker at a later time when the exchange rate favored the remitter. This was, then, an operation which allowed the loan to be repaid with interest (which was included in the new exchange rate), to the benefit of the original remitter. In the documentation which we examined, in only one case among the more than I,ooo exchange operations recorded in one year did we find the practice of protest used to conceal a loan. This protest occurred on 3I Jul. I4O3, when the Datini company of Barcelona was the recipient of the bill, while on 8 Aug. the company took on the role of remitter. This finding seems to qualify what the American historian claimed with regard to its frequent use. 
The mechanism of speculation in bills of exchange, meanwhile, can be clarified by describing a hypothetical situation based on real data. On 5 August I 395 in Palma de Mallorca, Tom paid I real for a bill of I 5.5 Barcelonan soldi to be paid to Dick (within the usual time period - Io days from presentation of the bill). On 3 September, Dick bought a return bill to be paid to Tom, using the I 5.5 soldi which he had just collected. On that day, the exchange rate in Mallorca was I4.9 6 soldi, such that with the I5.5 soldi Dick transferred I.039 reales to Palma, assuring Tom a substantial profit, amounting to 3.9 per cent for 29 days, or 49 per cent per annum (Nigro 20I6, p. 306). ${ }^{11}$

Operations of this nature, however, were characterized by a degree of uncertainty, represented by the real fluctuations of the exchange rates (it was indeed this unpredictability that enabled merchants to dodge the Church's condemnation): only if agents had prompt, accurate news of rate variations were they able to carry out profitable transactions. It comes as no surprise, then, that commercial correspondence contains frequent pleas for information, such as that made by Valenza Aliso degli Alberti to Cristofano Carocci in Palma: 'When you write again, tell us whether exchanges are being made there, not only ones directed here (Valencia) and to Barcelona, but also to Bruges, Avignon and Montpellier. And if so, give us the rates: if we find them favorable, we might make some as well' (Orlandi 2008, p. I40). ${ }^{12}$

In commercial and banking companies, purchases and sales of bills of exchange were recorded in the so-called book of exchange bills, whose sole purpose was to keep track of such operations: as such, this book represents the most specialized and technical record that basic accounting methods were capable of producing.

As we have indicated, our study focuses on an examination of the Book of Exchange Bills labeled ' $G$ ' from the Barcelonan branch of the Datini company. Here were recorded transfers of money and exchange operations carried out by this firm during the opening years of the fifteenth century. In particular, we looked at all operations involving monetary transfers, including bills of exchange that were purchased, sold, paid or redeemed by Simone Bellandi ${ }^{13}$ between 6 March I 403 and Io March I404. During that year, the Barcelonan firm recorded I,050 operations, of which I,038 were valid for our analysis. ${ }^{14}$ Overall, the firm moved 56,6I9,848

11 These figures are taken from ASPo, Datini, 842, Book of Exchange Bills, c. I 5 v. See also Nigro (20 I6).

12 Version in the original document: 'Quando ci scrivete ci avisate se costì si canbia per altrove che per qui e per Barzalona, ciò̀ per Brugia o per Vignone o per Monpulieri. E se vi si canbia, diretene di loro valute che per aventura, ci acadrà di trarvi o rimettervi alle volte se profitto vedessìno da ffare in niente.'

13 At the time, Simone Bellandi was director of the Datini company of Barcelona (Orlandi 2OIob).

14 Twelve operations were excluded, either because they lacked some data or because their exchange rates were inconsistent. The $\mathrm{I}, 038$ operations include transfers which did not involve currency 
Table I. Movement of money to and from Barcelona (6 March 1403-10 March 1404)

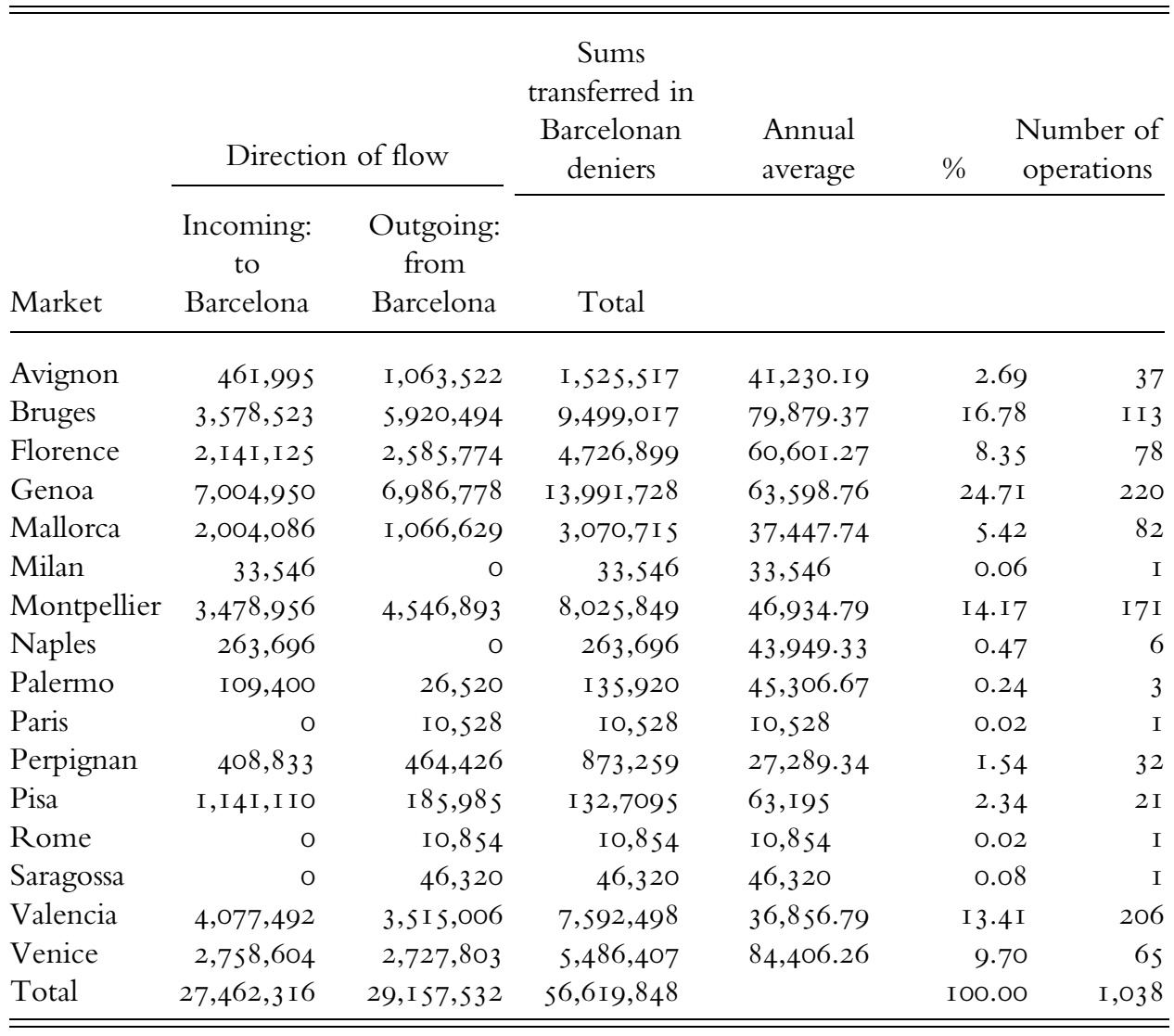

million deniers, equal to 235,916 Barcelonan pounds and 8 deniers. In Florentine florins this sum was equal to 277,548 florins 4 soldi and 8 deniers, which was quite a substantial amount if we consider that the share capital of the Barcelonan branch totaled 3,000 florins, while that of the entire Catalan company amounted to 9,600 florins (Melis I962, p. 248).

The markets involved in these money transfers were Avignon, Bruges, Florence, Genoa, Mallorca, Milan, Montpellier, Naples, Palermo, Paris, Perpignan, Pisa, Rome, Saragossa, Valencia and Venice - in other words, the most important markets of the period.

Table I and Figure I respectively indicate and illustrate the value of the monetary flows to and from Barcelona of the Datini branch operating in the Catalan capital. Overall, incoming and outgoing flows were equal, which could suggest that trade

exchange. As we will see below, of these $\mathrm{I}, 038$ transactions, only 930 were useful for analysis of exchange rate variations. 


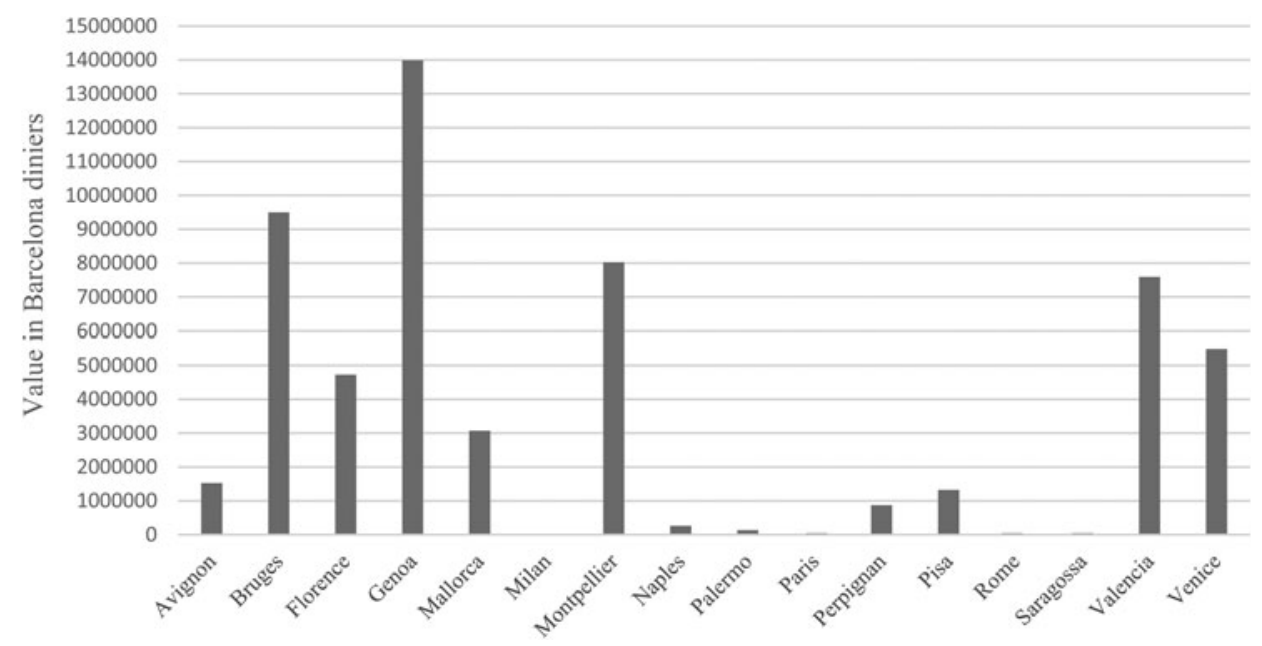

Figure I. Movement of money to and from Barcelona (6 March 1403-10 March 1404)

and payment balances in Barcelona were in substantial equilibrium. Yet this is not completely true because in general these flows were also the result of purely financial operations which could have various effects according to time and place. As examples, we have reconstructed the cases of Pisa and Avignon. With regard to the former, we know that monetary flows often underwent significant variations and that those values may contain sums earmarked for speculative activity or simple monetary transfers. During the year in question, Pisa functioned as a financial market more than a commercial one for the Barcelonan company. This circumstance accounts for the substantial difference between outgoing and incoming sums leaving and entering the Catalan capital. To better understand this difference, we examined the details of the commercial correspondence of $\mathrm{I}_{403}$, which reveals that the company of Lodovico and Francesco Borromei in Pisa played a role in the speculative triangulation with the Ricci banking firms in Genoa and Florence. This activity produced a web of financial flows which explain this discrepancy. ${ }^{15}$

The case of the Avignon company was different. The significant money flows that left the city toward Barcelona are evident from the month of June, when - as we shall see below - demand for money increased in the Catalan capital for the purchase of wool and kermes. This mechanism is once again confirmed by the correspondence: in June of that year, the director of the Barcelonan branch recommended to his counterpart in Avignon not to hold onto money from commercial operations carried out on his behalf but to transfer it to him as soon as possible. ${ }^{16}$

15 ASPo, Datini, 909, Pisa-Barcelona, Lodovico and Francesco Borromei to Francesco Datini and Andrea Bellandi and partners, 24 Mar. I403 and subsequent letters.

16 ASPo, Datini, 848, Avignon-Barcelona, Francesco Datini and Simone Bellandi, 25 Jun. I403. 
Let us now return to analyzing the money flows in light of what emerges from Table I. With nearly I4 million deniers, Genoa accounted for just under 25 per cent of the total of the transfers, followed by Bruges, Montpellier and Valencia, with I6.70 per cent, I4.I7 per cent and I3.4I per cent, respectively. Venice, Florence and Mallorca totaled 9.70 per cent, 8.35 per cent and 5.42 per cent, respectively. The nine other cities recorded a much lower involvement in these operations, with less than 2.69 per cent each.

If we sum the percentage values of the individual markets by geographical area, we find that the commercial operations of the Barcelona branch extended well beyond the region bounded by the Ebro and the Pyrenees. While this was the area in which the control of the company was most strongly felt, we can identify at least three others which attracted its attention.

The first of these regions is represented by north-central Italy, with Genoa, Pisa, Florence and Venice together accounting for 45.I per cent of the monetary flows under consideration. The importance of Genoa for the Barcelonan firm is readily comprehended, both because the Datini company here was responsible for establishing the Catalan branches and also because of geographical proximity, which naturally facilitated exchange. Ships leaving Genoa and Savona indeed brought a number of goods to Barcelona, including cloth, linen canvas, gold and silver thread, velvet, metal items such as small knives, fustian from Milan, and products from the Near East, such as cotton fabrics from Cyprus and Damascus. These were goods that were for the most part destined to meet the demand of the thriving Barcelonan market and those of Valencia and Mallorca. On the other hand, Barcelona sent Catalan cloth as well as leather and hides of various kinds to Liguria.

Florence and Pisa, meanwhile, supplied the Barcelonan market with woolen goods, fabrics of silk and gold thread, steel items, and paper from Colle Val d'Elsa; in exchange, they received leather goods and hides, coral rosaries, sugar and locally produced fabrics. Venice was the point of reference for trade with the Levant, Germany and the North Sea; the Datini company in that city purchased a great variety of products from Catalonia, including Spanish leather, wool from Maestrazgo and lute strings, and supplied the region in return with silver, paper, cotton, copper, rhubarb and spices.

A second region of interest was southern France, where Avignon and Montpellier were the focal points of an area of economic significance, accounting for I6.86 per cent of the monetary flows in question. Montpellier was the main port for the typical products of the Languedoc, especially cloth - an item much in demand throughout the Mediterranean - and woad; it traded these in return for kermes, indigo, wax, cloves and other products to be sold either in the local market or in those of cities to the north. Indeed, goods ascended the Rhône to reach Paris, from where trade routes continued to Bruges and London, which represented the ports of northern Europe with which the Barcelonan firm had most contact and where it purchased cloth manufactured in Essex, Mechlin, Wervik and Courtrai. In return, it shipped kermes, saffron, rice (Igual 20I6), cotton, spices, sugar, noci sarghe and other products. It was not by chance, then, that Bruges alone accounted for almost I7 per cent of 
the monetary flows examined in this study. ${ }^{17}$ It goes without saying that a very large part of trade with northern Europe followed the maritime routes which connected the Mediterranean with the Atlantic and the North Sea through the Strait of Gibraltar.

As we have indicated, the Barcelonan branch had extremely varied relations of collaboration and support with its two sister companies of Catalonia (Valencia and Mallorca); in the year under consideration, it transacted 10,663,213 Barcelonan deniers (almost I9 per cent of the total) with them. As the parent branch, it also acted on their behalf on the exchange and insurance markets, while with regard to commercial goods it carried out purchases and sales of their typical products. The two smaller branches of the Catalan company indeed benefitted from the significant position of the port and transport services of the Barcelonan branch within the complex system of international trade of the entire Datini group. In turn, the Barcelonan firm supplied its sisters with goods received in its own port from its correspondents in Genoa and Florence when these could not be sent directly.

The significant percentages of the monetary transactions with these three regions clearly illustrate their importance not only for the Barcelonan branch but also for the overall economy of the city. ${ }^{18}$ Table 2 shows the sums which the company transacted monthly through bills of exchange.

These figures clearly show that the periods during which the firm transferred the greatest sums were those between June/July and September/October. This should come as no surprise: kermes from Valencia and wool from Aragon and the Plain were usually purchased in the summer months. Our data indicate significant movements of money in the month of May as well, contrary to what is found in the Pratiche di mercatura, which often report phenomena that are generally valid but do not always correspond to reality, which is precisely the case with the difference between 'hearsay' and real exchange rates. This discrepancy is probably explained by the payment mechanisms for wool purchases: acquisitions were booked the previous autumn, and initial payments began as early as May, when shearing began. Indeed, the three months from May to July saw 302 exchange operations, with an average value of 56,706 deniers per contract.

In September and especially October, I 80 transactions were conducted for an average of 87,467 deniers per contract. It is probable that a substantial part of these regarded the purchase of saffron.

During the five months in question, over 27,000,000 deniers was transacted, nearly 48 per cent of the total. In general, it is interesting to note that precisely in the months of May, June, July, September and October the company recorded the highest income flows (Table 2), a fact which highlights the influence that trade had on monetary supply and demand and therefore on the factors of abundance and scarcity of money, which were crucial in determining exchange rates.

17 On the trade of the Datini company of Catalonia with the areas of Catalonia-Aragon and of northern Europe, see Guidi Bruscoli (2010) and Orlandi (20I9).

18 For an overview of the system of Barcelonan commerce, see Orlandi (20 Iob). 
Table 2. Monthly movements of money to and from Barcelona (6 March 1403-10 March 1404)

\begin{tabular}{|c|c|c|c|c|}
\hline \multirow[b]{3}{*}{ Month } & \multicolumn{3}{|c|}{ Sums moved in Barcelonan deniers } & \multirow[b]{3}{*}{$\begin{array}{c}\text { Number of } \\
\text { operations }\end{array}$} \\
\hline & \multicolumn{3}{|c|}{ Direction of flow } & \\
\hline & $\begin{array}{c}\text { Leaving } \\
\text { Barcelona for }\end{array}$ & $\begin{array}{c}\text { Entering } \\
\text { Barcelona from }\end{array}$ & Total & \\
\hline March I 403 & 2,9 I I , 7 I 2 & $2, \mathrm{OI}$ I , I 47 & $4,922,859$ & 95 \\
\hline April I403 & I, 863,474 & 2,269, I I 7 & $4, \mathrm{I} 32,59 \mathrm{I}$ & 80 \\
\hline May I4O3 & $\mathrm{I}, 868,783$ & $3,476,2$ I 5 & $5,344,998$ & IOI \\
\hline June I 403 & $3,233,808$ & $4,053,246$ & $7,287,054$ & I 2 I \\
\hline July I 403 & $2,391,3$ I9 & $2, \mathrm{IOI}, 727$ & $4,493,046$ & 80 \\
\hline August $\mathrm{I}_{4} \mathrm{O} 3$ & $2,266,740$ & I,561,629 & $3,828,369$ & 83 \\
\hline September I 403 & $2,4 \mathrm{I} 2, \mathrm{O} 32$ & $3,454,8$ I 5 & $5,866,847$ & IO3 \\
\hline October I 403 & $\mathrm{I}, 982, \mathrm{IOI}$ & $2,028,3$ I 8 & $4,010,4 \mathrm{IO}$ & 77 \\
\hline November I 403 & I,720,932 & $\mathrm{I}, 703,37 \mathrm{I}$ & $3,424,303$ & 67 \\
\hline December I403 & $\mathrm{I}, 677,935$ & $3, \mathrm{I} 37,73 \mathrm{I}$ & 4,8 I 5,666 & $8 \mathrm{I}$ \\
\hline January I 404 & $\mathrm{I}, 754,340$ & $\mathrm{I}, 865,4 \mathrm{I} 2$ & $3,619,752$ & 68 \\
\hline February I 404 & $\mathrm{I}, 820,820$ & $\mathrm{I}, 955,8 \mathrm{I} 2$ & $3,776,632$ & 64 \\
\hline March I4O4 & 620,862 & 476,450 & I, 097,3 I 2 & I 8 \\
\hline Total & $26,524,858$ & $30,094,990$ & 56,6 I 9,848 & $\mathrm{I}, \mathrm{O} 38$ \\
\hline
\end{tabular}

\section{V}

As we have indicated, new forms of loans aiming at sustaining companies began to spread at the turn of the fourteenth to the fifteenth century. The significance of the bill of exchange in this context was not simply due to speculative operations but also to the need to transfer funds quickly from one business to another. Indeed, bills were bought and sold to satisfy the demand for currency on the part of commercial agents; the question of oscillations in exchange rates therefore played a key role in their decisions.

In our analysis of the exchange contracts made by the Datini company in Barcelona between March I4O3 and March I4O4, our database tallied 930 valid transactions. From the overall total we indeed eliminated all operations of monetary transfers which did not require an exchange of currency because the money in question was the same for both markets. For example, monetary flows to and from Valencia and Perpignan were made in Barcelonan pounds, which of course was the currency of reference in Barcelona itself. $^{19}$

19 To these cases must also be added others which regarded bills destined for Avignon, Florence, Genoa, Mallorca, Montpellier, Naples, Palermo and Venice. Analysis for Valencia was conducted only on those operations involving exchange between Aragonese florins and Barcelonan pounds. 
Table 3. Value of monthly currency exchange transactions with Bruges, Genoa and Montpellier (6 March 1403 - 10 March 1404)

\begin{tabular}{|c|c|c|c|}
\hline Month & $\begin{array}{c}\text { Bruges } \\
\text { (Barcelonan deniers) }\end{array}$ & $\begin{array}{c}\text { Genoa } \\
\text { (Barcelonan deniers) }\end{array}$ & $\begin{array}{c}\text { Montpellier } \\
\text { (Barcelonan deniers) }\end{array}$ \\
\hline March I 403 & 553,936 & $\mathrm{I}, 002, \mathrm{I} 68$ & 360,250 \\
\hline April I 403 & 866,077 & I,I07,29I & 426,906 \\
\hline May I403 & 614,626 & I,699,258 & 707,523 \\
\hline June I 403 & $\mathrm{I}, 094,303$ & I,632,659 & I, I 30,554 \\
\hline July I4O3 & 602,788 & 619,830 & 470,759 \\
\hline August $\mathrm{I}_{4} \mathrm{O} 3$ & $38 \mathrm{I}, 025$ & 594,280 & 804,704 \\
\hline September $\mathrm{I} 4 \mathrm{O} 3$ & 584, IOO & $\mathrm{I}, 242,067$ & $\mathrm{I}, 055,990$ \\
\hline October $\mathrm{I}_{4} \mathrm{O} 3$ & 533,900 & 961,835 & 896,292 \\
\hline November I 403 & 592,560 & 725,404 & 388,880 \\
\hline December I 403 & $\mathrm{I}, 327,672$ & $\mathrm{I}, 347,978$ & 470,196 \\
\hline January I 404 & 858,255 & 857,325 & 382,553 \\
\hline February $\mathrm{I}_{40} 4$ & $\mathrm{I}, 489,775$ & $\mathrm{I}, \mathrm{O} 42,2 \mathrm{I} 6$ & 575,065 \\
\hline March I4O4 & 0 & 433,640 & 254,578 \\
\hline Total & $9,499,017$ & I $3,265,95$ I & $7,924,250$ \\
\hline
\end{tabular}

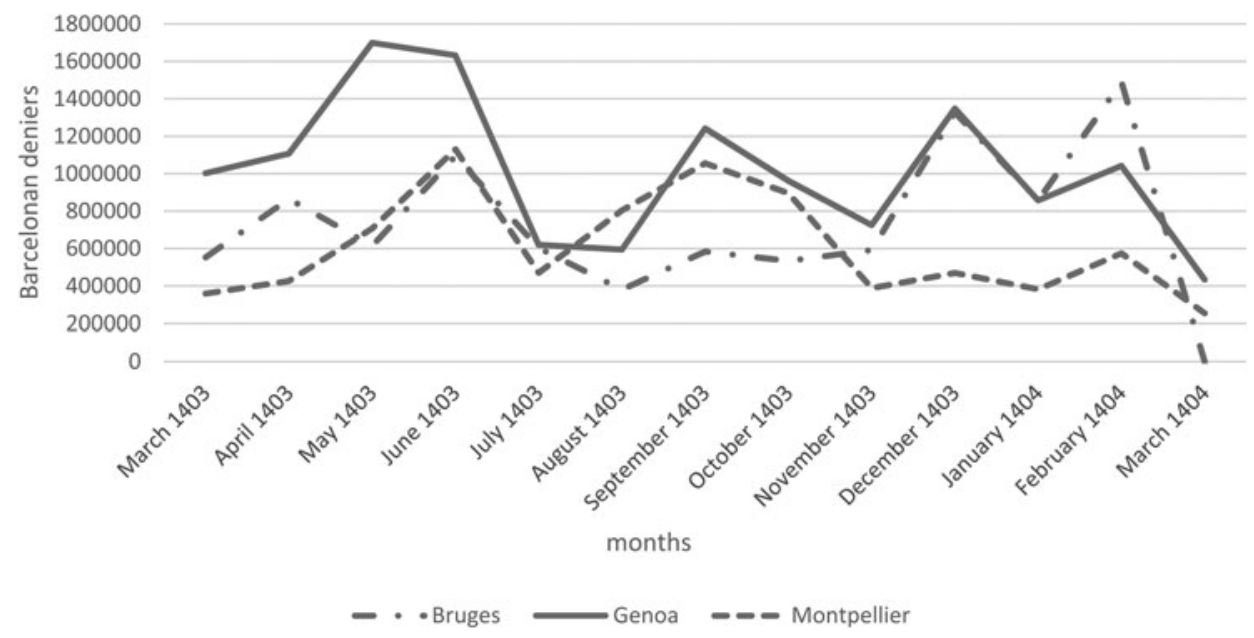

Figure 2. Value of monthly currency exchange transactions with Bruges, Genoa and Montpellier (6 March 1403- 10 March 1404)

In addition, we decided to examine sums transferred by means of bills of exchange and the relative fluctuations in exchange rates only for those cities which during the year under consideration recorded the greatest number of transactions and as such are the most relevant statistically, namely, Genoa (2 I2), Montpellier (I67) and Bruges (I I 3). 
A final point to bear in mind is that the method of exchange used in Barcelona was based on the price quotation system with regard to all markets: that is, the Catalan firm established rates based on an unknown amount of local currency (Melis I972, p. IOI).

Table 3 and Figure 2 show that with these three markets the Datini company of Barcelona exchanged 492 bills in foreign currency for a value of 30,689,2 I 8 deniers, representing almost 59 per cent of the total of $52,173,205$ deniers.

With regard to the exchange rates, we must bear in mind that money was treated in the same way as any other product: money, therefore, could be in great or short supply on the market. Commercial agents of the time called these situations monetary abundance or shortage, expressions that defined the greater or lesser quantity of local currency available on a particular market. Alternations between these phases naturally influenced fluctuations in exchange rates as well as the frequency of the operations concerning them. The correspondence of merchants provides ample proof of this fact: when, for example, money was in short supply in Valencia in August I395, Piero Tecchini wrote to Mallorca that 'there's a dearth of money on all markets' (Orlandi 2008, p. 652), ${ }^{20}$ a situation that would raise exchange rates.

A shortage or abundance of metallic money in circulation was above all due to internal mechanisms, such as variations in the cost of precious metals, the politics of the mints, occurrences of temporary or continuous hoarding, and the credit market. With regard to the last of these factors, we must bear in mind that during the I 380 s the Barcelonan money market underwent significant change. In the wake of the bankruptcy of several private bankers, the first public bank in Europe was created (on 20 January I4OI). This was the Taula de Canvi, which collected deposits from the municipal government, business operators and private citizens, thus playing a crucial role in influencing liquidity levels in the city (Feliu 2000; Orti Gost 2000, 200 I, 2007). As we will see, an even more important factor was the rhythms of commerce, which could produce variations in the prices of goods and the demand for foreign currencies. When ships arrived laden with goods the market prices of these products naturally decreased, while the demand for the currency of the country from which they came increased. On the whole, exchange rate oscillations depended on trade and payment balances. Exchange rates could be further influenced by liquidity in the foreign countries in question, by currency exchange speculation, and by interference on the part of governments (De Roover I968). In the period under consideration, however, we have no evidence of government meddling in the currency market. It is therefore likely that the most relevant factor behind oscillations in the price of money is to be ascribed to periods of currency abundance or shortage caused by commercial operations.

Merchants were well aware that the currency market passed through alternating phases of shortage and abundance and that these variations followed seasonal patterns, which were strongly conditioned by the movement of goods and the rhythms of navigation. In order to take advantage of these situations, commercial agents paid close

${ }^{20}$ Version in the original document: 'àcci fame di denari per ogni parte'. 
attention to each variation: their concern was to predict how and where fluctuations in the different exchange rates could occur.

If we wish to attempt to explain the rhythmic phenomena which characterized the Barcelonan market, we can make use of the evidence given in the Pratica di mercatura by Sanminiato de' Ricci, a Florentine merchant active in Genoa. Here he writes:

In Barcelona there's a lack of money from the first of June till the Feast of St. John because of the purchase of wool in Aragon, in the Plain and at the fairs. The same holds true for acquiring kermes in Valencia. We can therefore assume that the shortage continues throughout the month of August. Then it begins again for the purchase of saffron during the Feast of St. Luke in October. Purchase of saffron causes a shortage of money greater than that triggered by wool and kermes; during this period, whoever has cash makes great profits. The shortage lasts till January, then it gradually slows up and money returns to its previous prices, until the shortage caused by fresh purchases of wool and kermes. (Borlandi I963, p. I I 8 ) $^{21}$

We have, then, a lengthy period of currency shortage beginning in June and lasting until January; during these months, Barcelonan currency becomes stronger with respect to foreign monies, giving rise to high exchange rates.

Figures 3, 4 and 5 provide a good - even if not perfect - reflection of the observations made by Ricci. Indeed, for all three foreign currencies (the schild for Bruges, the genovino for Genoa and the franc for Montpellier) the curves show that the exchange rates begin to increase in the month of June and remain elevated until at least November. As we have seen, demand for local currency in those periods was high, above all for the purchase of wool, kermes, rice and saffron, products which Florentine and Genoese merchants present in Barcelona purchased not only for themselves but also on behalf of others.

This situation was accurately depicted by the merchants involved. For example, an agent of the Orlandini firm of Bruges wrote to the director of the Datini company in Barcelona in these words:

We believe that the cost of money there (in Barcelona) will come down when the stocks of saffron have been sold off. Keep us informed about this so we can be ready to make profits. Here (in Bruges) the cost of money of all currencies increased greatly, then it came down, and now we think these prices will continue for the rest of this month. Then, when the ships from Genoa arrive, things will change. We'll let you know. ${ }^{22}$

21 Version in the original document: 'A Barzalona à charestia di denari da dì primo di giugno fino a San Giovanni, per investire in lane in Raghona e nella piana, e nelle fiere, e anchora per investire in grane che si chomperano a Valenza. Siché si può ragionare v'è charo tutto aghosto.

Poi chomincia d'ottobre, per lo investire si fa per lo Santo Lucha in zafferano, e sempre v'è charo grande più che per lane e grane; e chi vi si ritruova chon danari vi fa gran profitti. E dura fino a genaio questa charestia, poi ongni dì vi s'alargha e tornano su loro primi pregi fino a l'antro tempo delle lane e grane.'

22 Version in the original document: 'Noi crediamo chostì si verà alarghando, passato che fia la furia di zafferani e voi ce ne tenete bene avisati a cciò possiano provedere a' profitti nostri. Qui si strinse a questi molto forte a danari per ongni parte, poi ci s'è alquando alarghato e intorno a' pregi crediamo staranno 


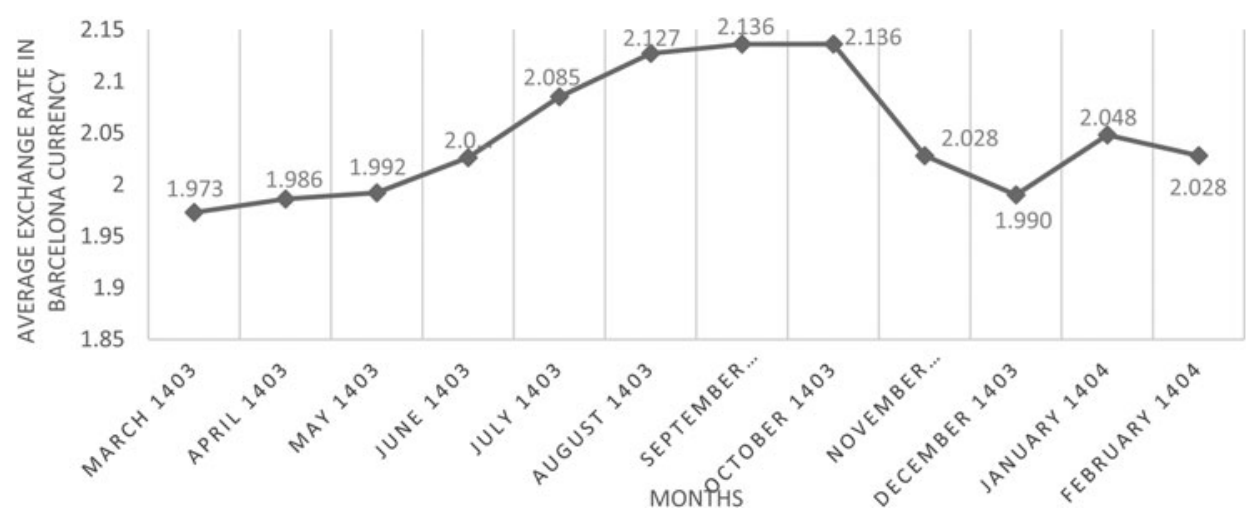

Figure 3. Average exchange rate fluctuations between the Brugeois schild and the Barcelonan pound (6 March 1403 - 10 March 1404)

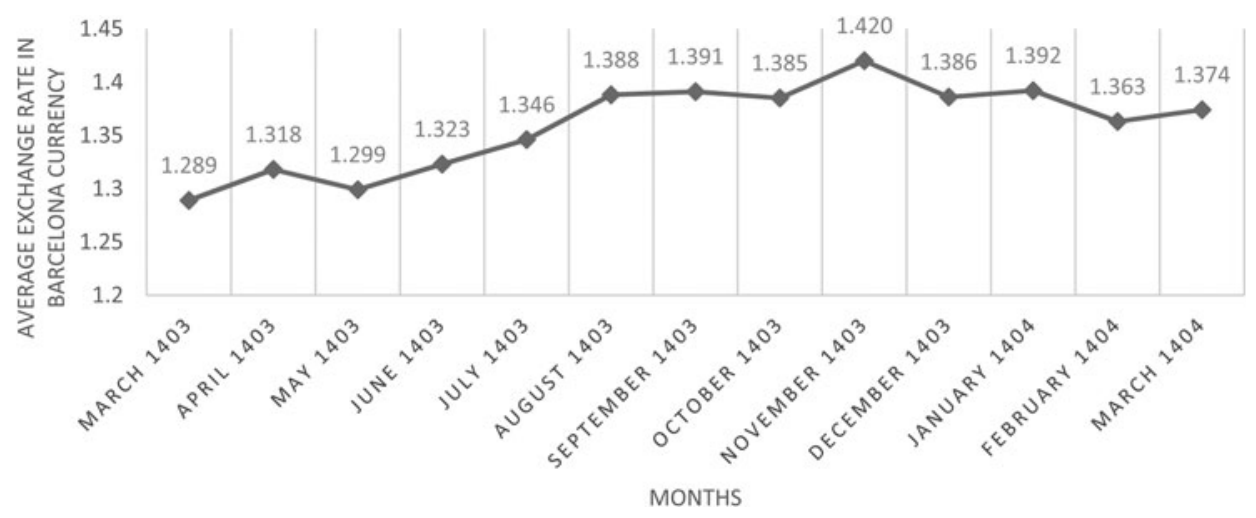

Figure 4. Average exchange rate fluctuations between the genovino and Barcelonan currency (6 March 1403 - 10 March 1404)

Our analysis reveals certain differences between real fluctuations and seasonal factors which have been noted by other studies on the contents of several Pratiche di mercatura. We find discrepancies with respect to what Sanminiato dei Ricci reported for the period between November and January. The Florentine merchant stated that the shortage of local money continued until the end of January; yet this claim is belied by Figures I and 3 (for Bruges and Montpellier), which are based on real exchange rates. As we have shown above, these rates differed from 'hearsay' ones more markedly

tutto questo mese. Poi quando ci fieno le navi genovesi faranno sechondo i bisongni: aviserenvi che seguirà.' ASPo, Datini, 853 , Bruges-Barcelona, Giovanni Orlandini and Piero Benizi and partners to Francesco di Marco Datini and partners, 6 Dec. I398, c. 2v. 


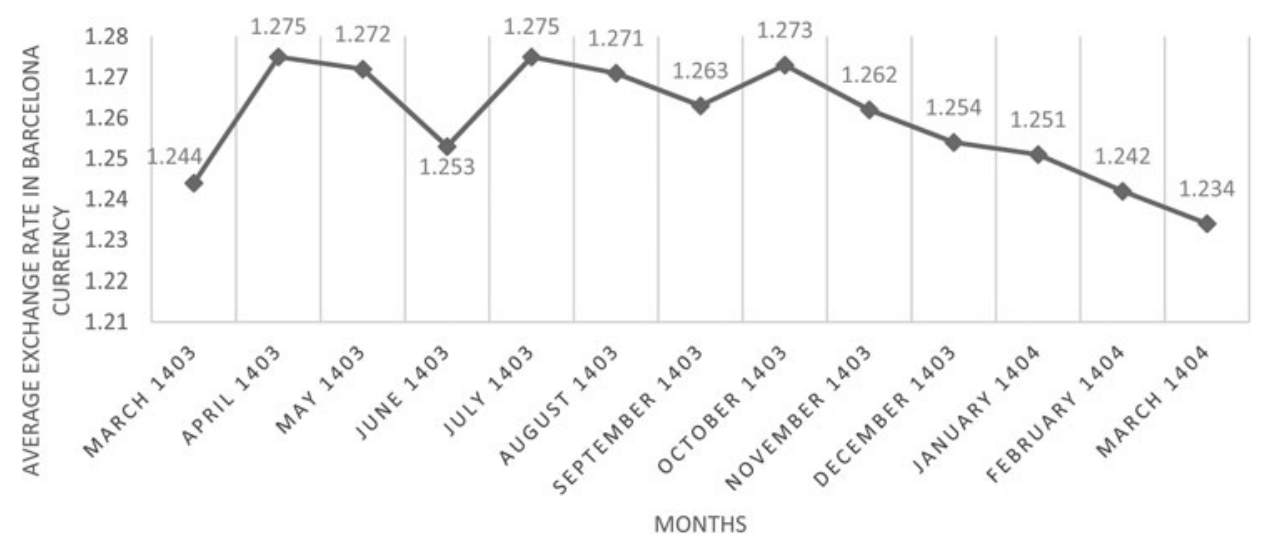

Figure 5. Average exchange rate fluctuations between the franc for Montpellier and Barcelonan currency (6 March 1403-10 March 1404)

during the winter months. Indeed, in the cases of both Bruges and Montpelier, the maximum difference was observed in the month of January, with the real exceeding the 'hearsay' rate by I 3.40 per cent and 6.85 per cent, respectively. It is therefore evident that using 'hearsay' rates would have produced distorted results. It was only through an exclusive use of real rates that we were able to conduct this innovative analysis.

The vibrant markets of the cities that we have examined indeed show dynamic variations in exchange rates. The best-informed agents were able to conclude their contracts by taking advantage of every opportunity, including those which might materialize during the course of a single day. The documentation clearly shows that exchange rates could be objects of negotiation between the parties. In a letter sent from Bruges, the company of Orlandini and Benezi wrote that on 9 September I 399 they made exchanges with Barcelona at varying rates: 'Today we exchanged at different prices: at s. 9 d. I I and at s. 9 d. Io, and then late in the evening, when we were about to send off the purse, at s. 9 d. Io $1 / 4$ I4;. Tomorrow the rates will be higher. ${ }^{23}$

This important detail from our sources allows us to make several salient observations. First of all, it shows the propensity of merchants to negotiate with their customers in order to gain maximum advantage. On that particular day, three different rates were applied; in the course of 24 hours, the value of a schild fell from s. 9 d. I I to s. 9

${ }^{23}$ Version in the original document: 's' è fatto oggi a più prego: a s. 9 d. I I e a s. 9 d. IO I/I e stasera, di notte, allo spacare della scharsella a s. 9 d. Io I/4, ma domane varanno più'. ASPo, Datini, 853, Bruges-Barcelona, Giovanni Orlandini and Piero Benizi and partners to Francesco di Marco Datini and partners, 9 Sep. I399, c. 2 v. 
d. I0.5, but in the evening, just as the purse was ready to be shipped, contracts were concluded at the rate of $5.9 \mathrm{~d}$. $10.25 .^{24}$

The hurry caused by the imminent departure of the postal service forced the remitter (the purchaser of the Barcelonan currency) to finalize the contract at a less favorable exchange rate. While in the morning a schild would buy 9 soldi I I deniers, by evening it exchanged for only 9 soldi I0.25 deniers.

Secondly, this particular letter points to a modest volatility in exchange rates, which apparently oscillated between minimum and maximum values of no great difference. While this circumstance confirms what emerged from the series of our database, at the same time it prompted us to broaden our analysis of exchange-rate variability with respect to the markets that traded with Barcelona during the period under examination. Indeed, in the next section of this article we will look at the temporal series of the exchange rates, making use of econometric tools. This analysis, which when combined with the more qualitative economic approaches employed thus far, will aid us in reading this volatility in a different light.

\section{$\mathrm{V}$}

In order to carry out an econometric analysis of exchange rate volatility on the Barcelonan market, we examined only those series which are made up of a sufficient number of readings to render the processing relevant. ${ }^{25}$ Overall, eight series meet this criterion: specifically, we analyzed the series of exchanges between the Barcelonan pound and the Avignon franc (AV), the Brugeois schild (BR), the Florentine florin (FL), the Genoese genovino (GE), the Mallorcan real (MA), the Montpellier franc (MP), the Aragonese florin of Valencia (VA) and the Venetian ducat (VE).

As we have seen, the temporal series of the available exchange rates cover a period from March I 403 to March I 404. The readings are irregularly spaced, in the sense that the exchange rates are recorded each time a transaction takes place. As a result, for each day a different number of exchange rate observations are available, greater than or equal to zero.

For each of the eight rates under consideration, we focused on the vector containing the series of the last exchange rates recorded for each day on which at least one transaction occurred. ${ }^{26}$ Formally, we use $X_{t}^{i}$ to denote the last value of the exchange rate for

24 With respect to Barcelona, Bruges exchanged on the volume quotation system, such that the exchange rate was based on an imaginary schild of 22 groot, converted into soldi and deniers of the Barcelonan pound.

25 All of the commercial markets included in the analysis had at least one transaction on 30 or more days. The series that have been excluded had transactions on only I 4 or fewer days. From a statistical point of view, it is clear that in terms of reliability of the estimated coefficients it would be inadvisable to attempt a fit in any econometric model on such small samples; this holds especially true for our limited reference period of roughly one year.

26 In other words, we analyzed the series of exchange rates corresponding to the last transaction in foreign currency conducted on a given day. The motivation behind this approach was to use the 


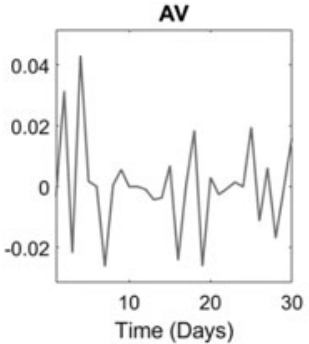

MA

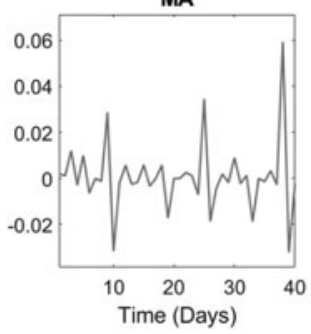

BR

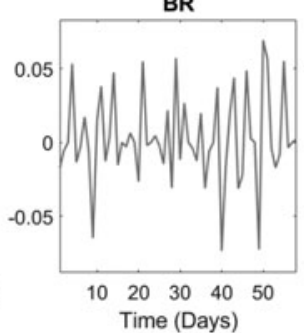

MP

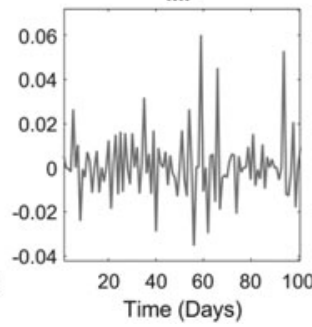

FL

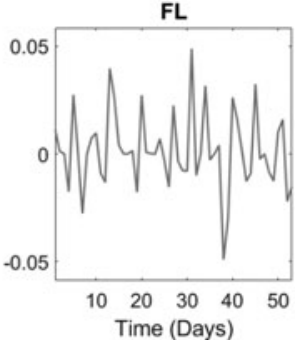

VA

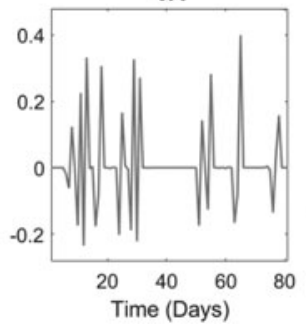

GE

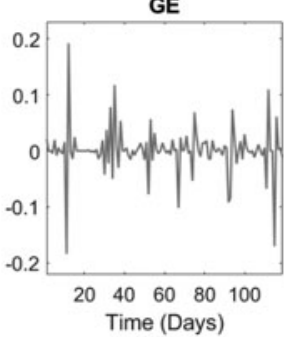

VE

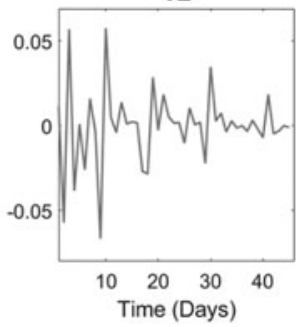

Figure 6. Scaled log-returns for the eight exchange rate samples analyzed

the $i$ th currency recorded on day $\mathrm{t}$, with $\mathrm{i}=\mathrm{I}, \ldots, 8$ and with $\mathrm{t}$ assuming values in the grid $G^{i}:=\left\{1=\tau_{1}^{i}<\tau_{2}^{i}<\ldots<\tau_{N_{i}}^{i}=N_{i}\right\}$, where $\tau_{j}^{i}$ is the integer corresponding to the $j$ th day with at least one transaction made in the $i$ th currency, and where $N_{i}$ is the total number of days with at least one transaction occurring with the ith currency.

To overcome the problem of readings which are irregularly spaced, we followed the

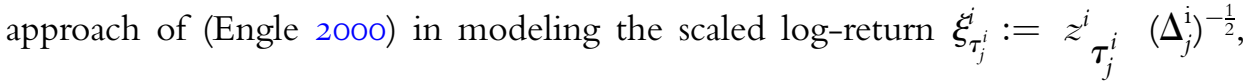
where $z_{\tau_{j}^{i}}^{i}:=\ln \left(X_{\tau_{j}^{i}}^{i} / X_{\tau_{j-1}^{i}}^{i}\right)$ and $\Delta_{j}^{\mathrm{i}}:=\tau_{j}^{i}-\tau_{j-1}^{i}$, with $\mathrm{j}=2,3, \ldots$ The series of scaled log-returns are plotted in Figure 6, while Table 4 shows some sample statistics of these series.

In order to decide which model is best suited to the univariate series of scaled logreturns, we began by testing for stationarity. The Augmented Dickey-Fuller test (Dickey and Fuller I979) confirmed that all our series of scaled log-returns could be assumed to be stationary, as the null hypothesis of the presence of a unit root was rejected at the 99 per cent confidence level for all the series. Then, we analyzed the sample autocorrelation functions of the scaled log-return series, which are illustrated in Figure 7.

The significant lag-I autocorrelations in Figure 7 suggested that an MA(I) model may represent a suitable fit for the series AV, GE, MA, MP, VA and VE. Instead, the absence

equivalent of the closing prices of contemporary financial markets, as financial time series are commonly analyzed by econometricians using the closing observation as the representative observation for a given day. As a robustness check, we repeated our analysis on the sequence of the daily averages of the recorded exchange rates, with results which were very similar to the ones obtained for end-of-day exchange rates. 
Table 4. Sample statistics of the scaled log-returns

\begin{tabular}{|c|c|c|c|c|c|}
\hline Sample & Mean & Variance & Skewness & Kurtosis & No. of observations \\
\hline Avignon & 0.0004 & 0.0002 & 0.5237 & $4.008 \mathrm{I}$ & 30 \\
\hline Bruges & 0.0029 & 0.0009 & -0.0090 & 3.4533 & 59 \\
\hline Florence & O.0OI 4 & 0.0003 & 0.2177 & 3.7199 & 53 \\
\hline Genoa & 0.0010 & 0.0018 & -0.3729 & I I.07I 3 & II 9 \\
\hline Mallorca & 0.0006 & 0.0002 & I. 2752 & 7.8335 & 40 \\
\hline Montpellier & 0.0009 & 0.0002 & I.IO3 I & 6.6448 & IOI \\
\hline Valencia & 0.0090 & O.0I39 & I.0476 & 5.3633 & $8 \mathrm{I}$ \\
\hline Venice & -0.0002 & 0.0005 & -0.2788 & 5.3173 & 46 \\
\hline
\end{tabular}

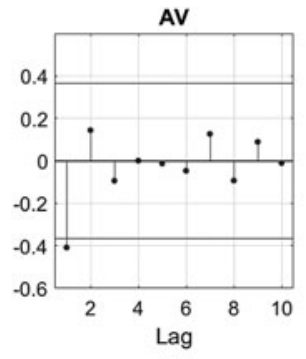

MA

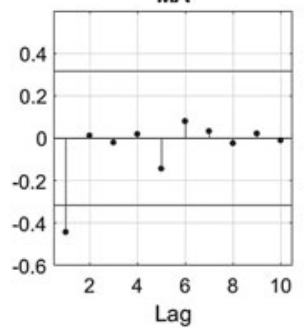

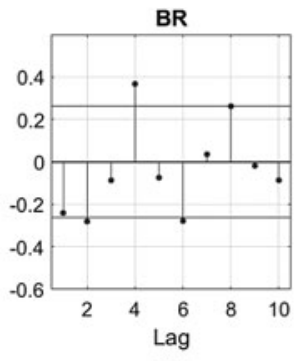

MP

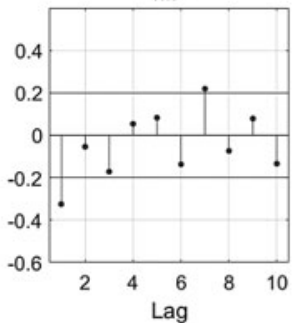

FL

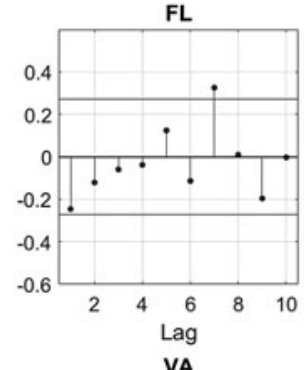

VA

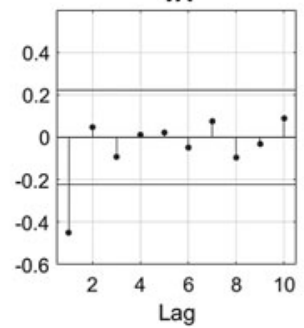

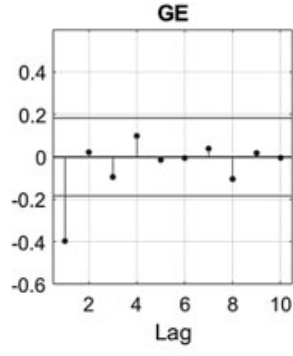

VE

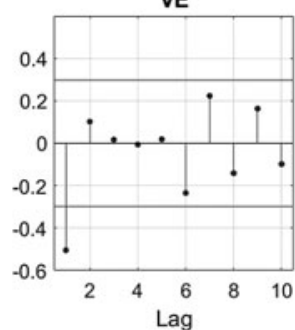

Figure 7. Sample autocorrelation functions for the eight exchange rate samples analyzed, with $95 \%$ confidence bounds for the null hypothesis of a white noise process

of significant autocorrelations indicated that a simple white noise may be sufficient to adequately model the series BR and FL. Furthermore, five out of the eight scaled logreturn samples, namely GE, MA, MP, VA and VE, failed the Jarque-Bera Gaussianity test (Jarque and Bera I987), performed at the 95 per cent confidence level. ${ }^{27}$ This is consistent with the values of sample kurtosis reported in Table 4.

27 The Jarque-Bera test is widely used in the literature on econometrics to verify that a sample has been drawn from a population with Gaussian distribution. It is essentially based on the comparison of the sample kurtosis and skewness with those of the normal distribution. In our analysis, the results of this 
Based on the overall analysis of univariate samples, we assumed the following model for the scaled log-returns:

$$
\xi_{\tau_{j}^{j}}^{i}=\epsilon_{\tau_{j}^{i}}^{i}+\beta^{i} \epsilon_{\tau_{j-1}^{i}}^{i}
$$

where, for each $\mathrm{i}=\mathrm{I}, \ldots, 8, \beta^{i}$ is a constant, $\boldsymbol{\epsilon}_{t}^{i}, t \in G^{i}$, is an i.i.d. sequence of t-distributed finite-kurtosis shocks with $v^{i}>_{4}$ degrees of freedom, mean equal to zero and variance equal to $\gamma^{i}:=v^{i}\left(v^{i}-2\right)^{-1}\left(\sigma^{i}\right)^{2}, \sigma^{i}>0$. Note that when $\beta^{i}=0$, this model corresponds to white noise and when $v^{i} \rightarrow \infty$ the shocks are Gaussian. We estimated this model on the time series of the eight available scaled log-returns using Maximum Likelihood. The results are summarized in Table 5 .

The presence of an MA(I) structure in six of the eight series shows that an economic agent could have predicted the exchange rate for the following transaction on the basis of the rate for the previous one.

In a certain sense, this result confirms the behavior of medieval merchant-bankers, who had no other way of attempting to predict exchange rates than by monitoring previously applied rates on a daily basis, if not several times a day. Not by chance, then, did agents communicate the 'hearsay' rates to their correspondents in nearly every letter. Over the medium and long term, they may also have taken circumstances of monetary abundance or shortage into account, which, as we have seen, caused variations in exchange rates. Indeed, in the absence of extraordinary events, the supply of money was known to merchants, who could make use of this knowledge to fine-tune their predictions of exchange rate fluctuations.

Analysis of the data showed us that six of the eight series examined revealed a correlation between one exchange rate and the previous one. With regard to these six series, then, a merchant could use this information to his advantage in the sale and purchase of bills of exchange.

On the other hand, the series for Bruges and Florence are well modeled by a white noise, that is, exchange rates which are independent of one another. For this reason, the exchange market between Barcelona, Bruges and Florence was more efficient. Indeed, it seems difficult to provide an explanation for these two series. For exchanges directed toward Bruges, we are able to show that during that year neither Barcelona nor the Flemish city totally adhered to predictions of monetary abundance and shortage expected on the two markets. From the beginning of June, in fact, Bruges showed an unusual abundance, caused by conflict between Florence and Pisa which rendered the ports of Motrone and Piombino inaccessible. ${ }^{28}$ The result was a reduction in the

test influence the choice of the random shock distribution in the next equation (I): this distribution is in fact selected in conformity with the results of this test for each analyzed series.

28 Regarding the abundance of the monetary supply recorded in Bruges, see ASPo, Datini, 855 BrugesBarcelona, 27 May I403, Giovanni Orlandini and partners to Francesco Datini and Simone Bellandi and partners, 27 May I403, c. Ir. De Roover (I968, p. 64) also examines this period of monetary abundance, which represented an unusual occurrence for the Flemish market. 
demand for the money required to load ships in the port of Sluys which were destined for the Mediterranean. In Barcelona, meanwhile, the exchange rate with Bruges was expected to rise between November and January, when it in fact fell, as we have noted.

Overall, univariate analysis finds low exchange rate volatility. Table 4 shows limited variance, from a minimum of 0.0002 in Avignon to a maximum of 0.0139 in Valencia. We see, then, that even in the absence of financial and banking institutions which control money markets from a centralized position - as occurs today - the price of money was quite stable. In their awareness of how much their own profits could depend on the correlation between one exchange rate and another, the merchants themselves probably aimed to limit variability. These circumstances of substantial stability meant that fluctuations in exchange rates were not at the root of the profits made by merchants through speculative activities, even if this possibility could never be completely ruled out; rather, earnings were based on the great quantities of money transferred from one market to another: small profit rates applied to large sums guaranteed significant revenues. ${ }^{29}$

Furthermore, by means of multivariate analysis we attempted to isolate the latent factors which affected fluctuations in the exchange rates between the markets of Florence, Genoa, Mallorca, Montpellier, Valencia and Venice during the year in question. We excluded Avignon and Bruges because we did not have at least one monthly datum for these cities. For the former, indeed, we have no observations for August I4O3 and January, February and March I404, while for the latter we have no data for March I404.

The availability of exchange rate samples for six different currencies calls for a multivariate approach. However, the possibility of performing robust and effective multivariate analysis directly on those samples is compromised by a problem of asynchronicity, that is, by the fact that each sample contains a different number of observations per day, greater than or equal to zero. Consequently, to cope with this lack of uniformity, we resorted to the same solution adopted by (Bell et al. 20I3), namely, we considered the series of monthly averages of intra-day exchange rates, which we denote by $M_{t}^{i}$, with i= $\mathrm{I}, \ldots, 6$ and $\mathrm{t}=\mathrm{I}, \ldots, \mathrm{I} 3$.

In particular, we performed Principal Component Analysis (PCA). Simply put, given a multi-dimensional random vector, PCA is concerned with using linear combinations of this random vector to explain the structure of its covariance matrix. As a dimension reduction technique, PCA is specifically used to isolate the few sources of variation that explain most of the total variance of a given random vector. A detailed treatment of PCA can be found, for example, in Tsay (20I0). We performed PCA on the standardized $\log$-returns $\tilde{w}_{\mathrm{t}}^{\mathrm{i}}:=\frac{\mathrm{w}_{\mathrm{t}}^{\mathrm{i}}-\mu^{\mathrm{i}}}{\sigma^{\mathrm{i}}}$, where $\mathrm{w}_{\mathrm{t}}^{\mathrm{i}}:=\ln \left(\frac{\mathrm{M}_{\mathrm{t}+1}}{\mathrm{M}_{\mathrm{t}}}\right), \mu^{\mathrm{i}}$ is the sample

29 For an idea of the substantial sums that were earned, we refer the reader to the basic case to which note Io alludes. 
Table 5. Results of the estimation of model (1) on the eight scaled log-return samples (p-values less than $10^{-3}$ are reported as zero)

\begin{tabular}{|c|c|c|c|c|}
\hline Sample & Model specification & Coeff. estimates & Std error & p-value \\
\hline Avignon & MA(I) with Gaussian shocks & $\begin{array}{c}\hat{\beta}^{i}=-0.4 \mathrm{I} 6 \\
\hat{\gamma}^{i}=\mathrm{I} .905 \cdot \mathrm{IO}^{-4}\end{array}$ & $\begin{array}{c}0.178 \\
4.068 \cdot \mathrm{IO}^{-5}\end{array}$ & $\begin{array}{l}\text { O.0I94 } \\
\text { o }\end{array}$ \\
\hline Bruges & Gaussian white noise & $\hat{\gamma}^{i}=9.189 \cdot \mathrm{IO}^{-4}$ & $\mathrm{I} .544 \cdot \mathrm{IO}^{-4}$ & o \\
\hline Florence & Gaussian white noise & $\hat{\gamma}^{i}=3.200 \cdot \mathrm{IO}^{-4}$ & $5.272 \cdot \mathrm{IO}^{-5}$ & o \\
\hline Genoa & MA(I) with Student t shocks $\left(\hat{v}^{i}=4.5\right)$ & $\begin{array}{c}\hat{\beta}^{i}=-0.379 \\
\hat{\gamma}^{i}=6.120 \cdot \mathrm{IO}^{-4}\end{array}$ & $\begin{array}{c}0.050 \\
7.688 \cdot \mathrm{10}^{-5}\end{array}$ & $\begin{array}{l}0 \\
0\end{array}$ \\
\hline Mallorca & MA(I) with Student t shocks $\left(\hat{v}^{i}=4.8\right)$ & $\begin{array}{c}\hat{\beta}^{i}=-0.55 \mathrm{I} \\
\hat{\gamma}^{i}=8.430 \cdot \mathrm{IO}^{-5}\end{array}$ & $\begin{array}{c}\text { O.1 } 23 \\
\text { I.910 } \cdot \text { 10 }^{-5}\end{array}$ & $\begin{array}{l}0 \\
0\end{array}$ \\
\hline Montpellier & MA(I) with Student t shocks $\left(\hat{v}^{i}=4.9\right)$ & $\begin{array}{c}\hat{\beta}^{i}=-0.369 \\
\hat{\gamma}^{i}=\mathrm{I} \cdot 47 \mathrm{I} \cdot \mathrm{IO}^{-4}\end{array}$ & $\begin{array}{c}0.077 \\
2.532 \cdot \mathrm{10}^{-5}\end{array}$ & $\begin{array}{l}0 \\
0\end{array}$ \\
\hline Valencia & MA(I) with Student t shocks $\left(\hat{v}^{i}=5 \cdot \mathrm{I}\right)$ & $\begin{array}{c}\hat{\beta}^{i}=-0.369 \\
\hat{\gamma}^{i}=9.167 \cdot \mathrm{IO}^{-3}\end{array}$ & $\begin{array}{c}0.084 \\
\text { I. } 543 \cdot \mathrm{IO}^{-3}\end{array}$ & $\begin{array}{l}0 \\
0\end{array}$ \\
\hline Venice & MA(I) with Student t shocks $\left(\hat{v}^{i}=4.2\right)$ & $\begin{array}{c}\hat{\beta}^{i}=-0.589 \\
\hat{\gamma}^{i}=3.197 \cdot \mathrm{IO}^{-4}\end{array}$ & $\begin{array}{c}0.089 \\
8.255 \cdot \mathrm{10}^{-5}\end{array}$ & $\begin{array}{l}0 \\
0\end{array}$ \\
\hline
\end{tabular}



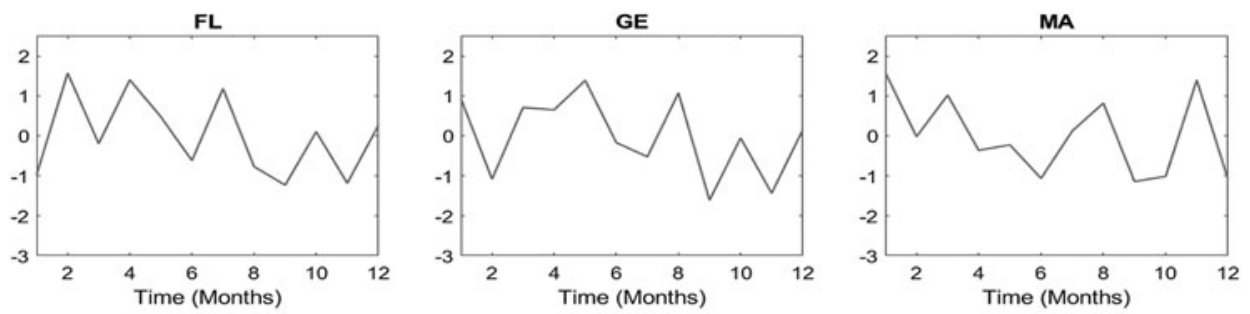

VA

VE
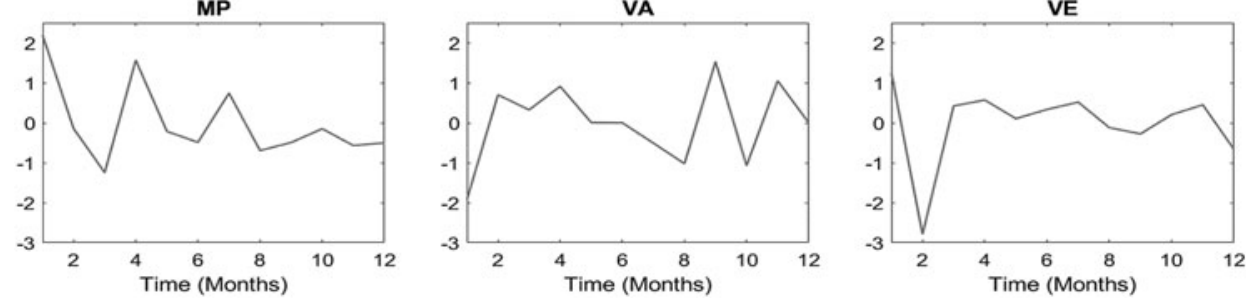

Figure 8. Monthly standardized log-returns

Table 6. Covariance matrix of the six series of monthly standardized log-returns

\begin{tabular}{lcccccc}
\hline \hline Sample / Sample & Florence & Genoa & Mallorca & Montpellier & Valencia & Venice \\
\hline Florence & I & & & & & \\
Genoa & O.I I I & I & & & & \\
Mallorca & -0.258 & $0.2 \mathrm{I} 6$ & I & & & \\
Montpellier & 0.258 & 0.229 & \multicolumn{1}{c}{0.200} & I & & \\
Valencia & $0.10 \mathrm{I}$ & -0.585 & -0.285 & -0.378 & I & \\
Venice & -0.424 & 0.383 & 0.300 & 0.362 & -0.363 & I \\
\hline \hline
\end{tabular}

mean of $\mathrm{w}_{\mathrm{t}}^{\mathrm{i}}$ and $\sigma^{\mathrm{i}}$ is its sample standard deviation. Figure 8 and Table 6 show, respectively, the plots and the sample covariance matrix of the $\tilde{w}_{\mathrm{t}}^{\mathrm{i}}$ s.

At first, we tested the univariate series of the $\tilde{w}_{\mathrm{t}}^{\mathrm{i}}$ 's for stationarity using the Augmented Dickey-Fuller test: we found that the null hypothesis of a unit root is always rejected at the 99 per cent confidence level. We then performed PCA of the available $\mathrm{I} 2 \times 6$ sample. The results are illustrated in Table 7 .

Table 7 shows that almost 40 per cent of the total variance of the data is explained by the first principal component and that the first two principal components alone explain more than 60 per cent of the total variance of the data. In particular, observation of the eigenvectors indicates that the first principal component ascribes positive weight to exchange rates related to financial operations concluded between Barcelona and exchange markets in the western Mediterranean (with the exception of Montpellier, for which the weight is approximately zero), while attributing negative weight to Florence and Venice, geographically more distant from Barcelona. This first principal component, which shows the same positive sign for those markets closest to 
Table 7. PCA of the covariance matrix in Table 6

\begin{tabular}{lcccccc}
\hline \hline Eigenvalues & 2.380 & $\mathrm{I} .390$ & 0.828 & 0.738 & 0.483 & \multicolumn{1}{c}{$0 . \mathrm{I} 84$} \\
\% of tot. var. explained & $39.65 \%$ & $23 . \mathrm{I} 6 \%$ & $\mathrm{I} 3.79 \%$ & $\mathrm{I} 2.29 \%$ & $8.05 \%$ & $3.07 \%$ \\
Cum. \% of tot. var. explained & $39.65 \%$ & $62.8 \mathrm{I} \%$ & $76.60 \%$ & $88.88 \%$ & $96.93 \%$ & \multicolumn{1}{c}{$\mathrm{I00} \%$} \\
& $-0.5 \mathrm{I} 9$ & -0.27 & $-0 . \mathrm{I} 75$ & 0.07 & -0.775 & $-0 . \mathrm{I} 49$ \\
& 0.439 & -0.445 & -0.079 & -0.57 & $-0.26 \mathrm{I}$ & 0.459 \\
Eigenvectors & -0.092 & $-0 . \mathrm{I} 66$ & $-0.8 \mathrm{O} 2$ & 0.344 & 0.262 & 0.365 \\
& $0.43 \mathrm{I}$ & $0 . \mathrm{I} 68$ & 0.23 & 0.654 & $-0.4 \mathrm{II}$ & 0.369 \\
& 0.329 & $-0.7 \mathrm{I}$ & $0.06 \mathrm{I}$ & 0.322 & $0 . \mathrm{I} 4 \mathrm{I}$ & $-0.5 \mathrm{II}$ \\
& -0.486 & $-0.4 \mathrm{I} 2$ & $0.5 \mathrm{I} 3$ & $0 . \mathrm{I} 43$ & 0.273 & 0.486 \\
\hline \hline
\end{tabular}

Barcelona, may thus be interpreted as having geographical relevance. Shorter distances may have meant a more rapid exchange of news between one city and another, including information on exchange rates, as well as greater and faster coordination and synchronization of decisions regarding economic operations. This hypothesis may find further confirmation in the fact that Florence and Venice counted for only 9 per cent and 8 per cent, respectively, of the monetary transactions to and from Barcelona, as shown in Table $\mathrm{I}$.

The second principal component, on the other hand, ascribes negative weight to all five series except that for Montpellier. This component may therefore be interpreted as having macroeconomic relevance, with roughly the same effect on five of the six exchange rate log-returns. This macroeconomic factor may then be linked to commercial activity. We have seen that relations with Valencia and Mallorca were inevitably close, not only with regard to trade within the area of Catalonia and Aragon but also for operations toward other markets in the western Mediterranean, the North Sea and the African coast. Genoa, Florence and Venice, meanwhile, were the three main markets of the period with which Barcelona had close commercial contacts, whether directly or indirectly.

\section{VI}

This study has provided us with further significant information about the intensive use of bills of exchange made by commercial agents. By assuring a more rapid circulation of money, these bills exerted beneficial effects - as Giampiero Nigro has written - on economies such as those of Barcelona, Valencia and Mallorca: albeit in different ways, these markets were each characterized by growing productive and commercial capacity and a relatively high rate of monetization (Nigro 20I6, p. 298). At the same time, we must bear in mind that in the Catalan capital the exchange bill market was largely managed by Florentine and Tuscan operators working together with agents from Genoa and Milan and with local businessmen (Feliu 2004, 2007; Orti 2000, 2007). This dominant role - both from the commercial and financial points 
of view - of Tuscan merchant-bankers and in particular of those of Datini companies allows us to make the claim (with all due caution) that the results of this study provide a fairly reliable representation of the Barcelonan exchange market.

Although the account book upon which we have relied for this study does not allow us to precisely identify the purposes for which exchange contracts were issued, we are inclined to believe that they were principally used to transfer funds needed to satisfy a great variety of requirements for liquidity. This primary function therefore enables us to answer the first question that we posed at the outset: the most intense financial flows of the Barcelonan firm were with those markets with which it had the closest commercial relations. As we have seen, these were Genoa, Montpellier and its region, and Bruges, which was a true point of reference for trade with northern Europe.

At the same time, the bill of exchange could also be used for loans and for speculative operations on financial markets. In that case, it was essential for commercial agents to be able to predict the volatility of exchange rates.

With regard to our second and more articulated question regarding the reasons for and the modalities and predictability of exchange rate oscillations, we have seen that currency prices were affected by a number of elements, which we have discussed. We have seen that one of the traditional factors was the supply of and demand for money. We know that vacillations between conditions of shortage or abundance of local money were especially connected to fluctuations in the balance of trade and in payments. The Pratiche di mercatura and the comments of agents always tend to emphasize that liquidity on those markets influenced the rhythms of the exchange of products such as wool, kermes, saffron and rice. Fluctuations in the series which we reconstructed essentially reflect conditions of liquidity caused by commercial flows, even if several variations due to institutional conflict, the movement of ships, and monetary policy could also come into play.

In particular, we have seen that seasonal variations in exchange rates are not always confirmed by the study of real rates. Indeed, exchange rates between the currency of Barcelona and those of Bruges and Montpellier differed from those predicted in the Pratiche di mercatura and effectively expressed by 'hearsay' rates. On the other hand, 'hearsay' rates could not account for rates that spontaneously resulted from negotiations between contracting parties, which, we believe, were often determined by speculative operations. In any case, these negotiated rates played a role in defining fluctuations on the currency market.

Econometric analysis then impelled us to assess other aspects of exchanges, including their markets and their volatility. In particular, this part of the study shows low rate variability, indicating substantial stability, which aided merchants in reducing the risks of speculative operations. As we have seen, this stability enabled operators to profit by moving considerable sums from one market to another.

Finally, multivariate analysis led us to consider the predictability of exchange rates. In addition, this analysis suggests the probable role of geographical and macroeconomic factors able to influence rates. With regard to the former, the geographical 
proximity of certain areas perhaps allowed for more rapid circulation of news by means of commercial letters - precious sources of information, including currency prices. With reference to the latter factor, commercial activity represented a powerful motor in the economy of the time.

A fundamental role in these questions was played by the skill of merchants - their training and their knowledge of the markets and of economic and financial mechanisms: the result of all this expertise was, incredibly, that the price of money was kept at almost stable levels. Commercial agents were indeed able to profit not only when favorable exchange rates made their lives easy but also when white noise complicated their efforts.

Submitted: I 8 December 2020

Revised version submitted: I 8 February 202 I

Accepted: I6 March 202 I

\section{Sources}

State Archive of Prato, Fondo Datini, nn. 842, 848, 853, 855, 909

\section{References}

BELL, A., BROOKS, C. and MOORE, T. (2OI3). Medieval foreign exchange: a time series analysis. In M. Casson and H. Nigar (eds.), Large Database in Economic History; Research Methods and Case Studies. Abingdon: Routledge.

BELL, A., BROOKS, C. and MOORE, T. (2OI7a). Cambium non est mutuum: exchange and interest rates in medieval Europe. Economic History Review, 70(2), pp. 373-96.

BELL, A., BROOKS, C. and MOORE, T. (2017b). Did purchasing power parity hold in medieval Europe? The Manchester School, 85(6), pp. 682-709.

BORLANDI, A. (1963). Il manuale di mercatura di Saminiato de’ Ricci. Genoa: Di Stefano.

BÖRNER, L. and HATFIELD, J. W. (20I7). The design of debt-clearing markets: clearinghouse mechanisms in Preindustrial Europe. Journal of Political Economy, I25(6), pp. I99I-2037.

CASADO ALONSO, H. (20I5). Circuitos comerciales y flujos financieros en Castilla a fines de la Edad Media e inicios de la Modernidad. In Má. Ladero Quesada (ed.), Estados y mercados financieros en el Occidente cristiano (siglos XIII-XVI). Pamplona: Gobierno de Navarra.

DAVID, I. (20I6). Vom Feld aufs Schiff: Handel und Export von Reis aus Valencia nach Flandern im Spätmittelalter. Hansische Geschichtsblätter, I34, pp. 6I-95.

DE BONIS, R. and VANGELISTI, M. I. (20I9). Moneta. Dai buoi di Omero ai Bitcoin. Bologna: il Mulino.

DE ROOVER, R. (I953). L'evolution de la lettre de change (XIVe-XVIIIe siècles). Paris: Armand Colin.

DE ROOVER, R. (I968). The Bruges Money Market around 1400. Brussels: Paleis der Akademien.

DICKEY, D. A. and FULLER, W. A. (I979). Distribution of the estimators for autoregressive time series with a unit root. Journal of the American Statistical Association, 74, pp. 427-43.

ENGLE, R. (2000). The econometrics of ultra-high frequency data. Econometrica, 68, pp. I-22.

FELIU, G. (2000). Moneda y banca en Cataluña en el siglo Xv. In A. M. Bernal (ed.), Dinero, moneda y crédito en la monarquía hispánica. Actas del simposio internacional (Madrid, 4-7 de mayo de I999). Madrid: Marcial Pons.

FELIU, G. (2004). La disputa de los libros contables en la quiebra de la 'Taula de Canvi' de Pere des Caus y Andreu d'Olivella (I38I). Revista española de financiación y contabilidad, I20, pp. 95-I24.

FELIU, G. (2007). Mercaders-banquers barcelonins: l'endeutament de la monarquia i la fallida de la taula de canvi de Pere des Caus i Andreu d'Olivella el I38I. In M. Sánchez Martínez (ed.), El món del crèdit a la Barcelona medieval. Barcelona Quaderns d'Història, I3, pp. I97-2 Iо. 
FLANDREAU, M., GALIMARD, C., JOBST, C. and NOGUES-MARCO, P. (2009). Monetary geography before the Industrial Revolution. Cambridge Journal of Regions, Economy and Society, 2(2), pp. I49-7I.

GOLDTHWAITE, R. (20I3). L'economia della Firenze rinascimentale. Bologna: il Mulino.

GUIDI BRUSCOLI, F. (2010). I rapporti con il Nord-Europa. In G. Nigro (ed.), Francesco di Marco Datini: The Man the Merchant. Prato and Florence: Fondazione Istituto Internazionale di Storia Economica 'F. Datini'-Prato, FUP.

JARQUE, C. M. and BERA, A. K. (1987). A test for normality of observations and regression residuals. International Statistical Review, 55, pp. I63-72.

KOYAMA, M. (20I0). Evading the 'taint of usury': the usury prohibition as a barrier to entry. Explorations in Economic History, 47, pp. 420-42.

MARSILIO, C. (2OIOa). Fiere di cambio italiane e mercato del credito europeo: la rivalità tra gli operatori finanziari genovesi e fiorentini nella prima metà del XVII secolo. In G. Sabatini (ed.), Comprendere le monarchie iberiche. Risorse materiali e rappresentazioni del potere. Rome: Viella.

MARSILIO, C. (2OIOb). Four times a year for so many years: the Italian Exchange Fairs during the XVIth-XVIIth centuries: comparing financial institutions. Bankhistorisches ArchivBanking and Finance in Historical Perspective, 36(2), pp. I I I-65.

MARSILIO, C. (20 I Ia). Cumplir con cuidado: il mercato del credito genovese negli anni I630-I640. Vecchi protagonisti e nuove strategie. In M. Herrero Sánchez, Y. Rocío Ben Yessef Garfia, C. Bitossi and D. Puncuh (eds.), Génova y la Monarquía Hispánica (1528-1713). Genoa: Società Ligure di Storia Patria.

MARSILIO, C. (20I Ib). Gli Spinola di San Pietro protagonisti del sistema politico-finanziario internazionale (secc. XVII-XVIII). In R. Roberto Santamaria (ed.), Palazzo Doria Spinola a Genova: $i$ Duchi di San Pietro e le loro collezioni da un inventario del 1727. Recco: Le mani, Recco.

MARSILIO, C. (20I Ic). La lunga avventura delle fiere di cambio: da Lione a Novi. In A. Sisti and M. Balbi (eds.), Libri italiani del Seicento nel fondo antico della Biblioteca Civica di Novi Ligure. Novi Ligure: Città del silenzio edizioni.

MARSILIO, C. (2OI 2a). O dinheiro morreu: paz à sua alma danada. Gli operatori finanziari del XVII secolo tra investimenti e speculazioni. Palermo: Associazione Mediterranea.

MARSILIO, C. (2OI $\mathrm{b}$ ). The Genoese and Portuguese financial operators' control of the Spanish silver market (I627-I657). Journal of European Economic History, 4I(3), pp. 67-89.

MARSILIO, C. (20I2c). Genoese finance, I $348-$ - 700 . In G. Caprio (ed.), Handbook of Key Global Financial Markets, Institutions, and Infrastructure, vol. I. Oxford: Elsevier.

MARSILIO, C. (2014). Pallavicino, Paolo Gerolamo. In Dizionario Biografico degli Italiani. Rome: Treccani.

MARSILIO, C. (20I5a) The Genoese exchange fairs and the Bank of Amsterdam: comparing two financial institutions of the I7th century. História Econômica \& História de Empresas, I8(I), pp. 39-59.

MARSILIO, C. (20I5b). 'Un homme avisé est capable de faire face à toutes les catastrophes': les compétences professionnelles des opérateurs financiers génois, florentins et portugais à l'époque des foires de change du XVIIE siècle. In K. Béguin (ed.), Ressources publiques et construction étatique en Europe XIII $-X V I I I^{\mathrm{e}}$ siècle. Paris: Institut de la gestion publique et du développement économique.

MARSILIO, C. (20I6). 'Sono tempi che corrono accidenti non prevedibili': come gli hombres de negocios genovesi (re)agirono alle insolvenze della corona spagnola (I62 I-I648) tra speculazioni finanziarie e mercato del credito e dei metalli preziosi. Le crisi finanziarie: gestione, implicazioni sociali e conseguenze nell'età preindustriale - The Financial Crises: Their Management, Their Social Implications and Their Consequences in Pre-Industrial Times. Selezione di ricerche - Selection of essays. Prato and Florence: Fondazione Istituto Internazionale di Storia Economica 'F. Datini'-Prato, FUP.

MARSILIO, C. (20 I 8). Exchange Fairs and the Money Market in Early Modern Italy (1630-I650) - Fiere di cambio e mercato monetario nell'Italia di età moderna (1630-1650). Recco: Città del silenzio.

MARTÍNEZ RUIZ, I. J. (2004). The credit market and the profits from the letters of exchange. Ricorsa exchange operations between Seville and the Besançon fairs (I589-I62I). Journal of European Economic History, 33(2), pp. 33 I-55.

MELIS, F. (I962). Aspetti della vita economica medievale (Studi nell'Archivio Datini di Prato). Florence: Olschki.

MELIS, F. (1972). Documenti per la storia economia dei secoli XIII-XVI. Florence: Olschki. 
NEAL, L. (2000). How it all began: the monetary and financial architecture of Europe during the first global capital markets, I648-I8 I5. Financial History Review, 7(2), pp. I I7-40.

NIGRO, G. (20I6). Aspetti del movimento finanziario in area aragonese nella documentazione mercantile toscana (secoli XIV-XV). Una premessa: la lettera di cambio tra attività feneratizie e trasferimento fondi. In P. Iradiel, G. Navarro, D. Igual and C. Villanueva (eds.), Identidades urbanas. Corona de Aragón-Italia. Redes económicas, estructuras institucionales, funciones políticas (siglos $X I V-X V)$. Zaragoza: PUZ.

NOGUES-MARCO, P. (20I7). Money markets and exchange rates in pre-industrial Europe. Paul Bairoch Institute of Economic History, Université de Genève, Working Papers 7.

ORLANDI, A. (2008). Mercanzie e denaro: la corrispondenza datiniana tra Valenza e Maiorca (1395-1398). Valencia: Universitat de València.

ORLANDI, A. (20IOa). A man from Prato in the Maestrazgo: Tuccio di Gennaio, wool merchant. In G. Nigro (ed.), Francesco di Marco Datini. The Man the Merchant. Prato and Florence: Fondazione Istituto Internazionale di Storia Economica 'F. Datini'-Prato, FUP.

ORLANDI, A. (2010b). The Catalonia Company: an Almost Unexpected Success. In G. Nigro (ed.), Francesco di Marco Datini: The Man the Merchant. Prato and Florence: Fondazione Istituto Internazionale di Storia Economica 'F. Datini'-Prato, FUP.

ORLANDI, A. (20I6). Aspetti del movimento finanziario in area aragonese nella documentazione mercantile toscana (secoli xIV-XV). Un caso di studio: l'andamento dei cambi tra Barcellona, Valenza, Palma di Maiorca. In P. Iradiel, G. Navarro, D. Igual and C. Villanueva (eds.), Identidades urbanas. Corona de Aragón-Italia. Redes económicas, estructuras institucionales, funciones políticas (siglos $X I V-X V)$. Zaragoza: PUZ.

ORLANDI, A. (20I9). Between the Mediterranean and the North Sea: networks of men and ports (I4th-I sth centuries). Reti marittime come fattori dell'integrazione europea - Maritime Networks as a Factor in European Integration. Prato and Florence: Fondazione Istituto Internazionale di Storia Economica 'F. Datini'-Prato, FUP.

ORTI GOST, P. (2000). Renda i fiscalitat en una ciutat medieval: Barcelona. Segles XII-XIV. Barcelona: CSIC.

ORTI GOST, P. (200I). El Consell de Cent durant l'Edat Mitjana. Barcelona Quaderns d'Història, 4, pp. $2 \mathrm{I}-48$.

ORTI GOST, P. (2007). Les finances municipals de Barcelona: del censal a la Taula de Canvi. In M. Sánchez Martínez (ed.), El món del crèdit a la Barcelona medieval. Barcelona Quaderns d'Història, I3, pp. 257-82.

PEZZOLO, L. and TATTARA, G. (2008). 'Una fiera senza luogo?' Was Bisenzone an international capital market in sixteenth-century Italy? Journal of Economic History, 68(4), pp. I098-I I 22.

PUNCUH, D. (2002). Il documento commerciale in area mediterranea. In Libri, documenti, epigrafi medievali: possibilità di studi comparativi. Atti del Convegno internazionale di studio dell'Associazione Italiana dei Paleografi e Diplomatisti, Bari, $2-5$ ottobre 2000. Spoleto.

QUINN, S. and WILLIAM, R. (2006). An economic explanation of early bank of Amsterdam, debasement, bills of exchange, and the emergence of the first central bank. Federal Reserve Bank of Atlanta, Working Papers, I 3 .

RUBIN, J. (20I0). Bills of exchange, interest bans, and impersonal exchange in Islam and Christianity. Explorations in Economic History, 47(2), pp. 21 3-27.

SÁNCHEZ DEL BARRIO, A. (20 I 5). Las ferias de Medina del Campo. Novitate, 30.I(59), pp. IO-I8. SAPORI, A. (I970). Libro giallo della Compagnia dei Covoni. Milan: Cisalpino.

SAYOUS, A. E. (I975). Els mètodes comercials a la Barcelona medieval. Barcelona: Editorial Base.

TOCCAFONDI, D. (2004). L'Archivio Datini: formazione e trasmissione di un archivio mercantile. In E. Cecchi Aste (ed.), L'Archivio di Francesco di Marco Datini, Fondaco di Avignone. Rome: Ministero per i Beni e le Attività Culturali.

TSAY, R. S. (20I0). Analysis of Financial Time Series. Hoboken, NJ: Wiley. 